\title{
Differences in hepatic growth hormone receptor binding during development of normal and dwarf chickens
}

\author{
A Vanderpooten $1^{*}$, LM Huybrechts 1, E Decuypere 2, ER Kühn 1
}

${ }^{1}$ Laboratory of Comparative Endocrinology, Naamsestraat 61, B-3000 Leuven;

2 Laboratory of Physiology and Immunology of Domestic Animals, $K$ Mercierlaan 92, B-3030 Leuven, Belgium

(Received 31 August 1990; accepted 12 November 1990)

\begin{abstract}
Summary - The aim of this study was to compare the growth hormone (GH) receptor in liver microsomal fractions of normal chickens (Dw) and chickens carrying the dwarf gene (dw). Specific binding of $\mathrm{GH}$ to its hepatic receptor was significantly higher for Dw embryos from d 14 till $d 20$ of incubation than for $\mathrm{dw}$ embryos. The difference in binding was due to a decreased binding capacity but not affinity in the livers of the dwarf embryos. The same binding pattern was found in livers of adult chickens: lower binding was again caused by a lower number of GH receptors and at this stage the difference was even clearer than during embryonic development. Binding studies on livers of growing chicks demonstrated that binding was low for both genotypes, but a small though significant difference between them remained. The cause of this decrease in number of GH receptors in dwarf birds has yet to be determined but may be due to the primary action of the dwarf gene.
\end{abstract}

chicken / growth hormone receptor / dwarf

Résumé - Différence de liaison de l'hormone de croissance à son récepteur hépatique pendant le développement des poules normales et des poules naines. L'objectif de cette étude était de comparer le récepteur de l'hormone de croissance (GH) dans les fractions microsomales hépatiques des poules normales ( $D w$ ) et des poules portant le gène de nanisme lié au sexe (dw). La liaison spécifique de GH à son récepteur hépatique est plus élevée chez les embryons Dw que chez les embryons $d w$ du $14^{e} j$ au $20^{\circ} j$ d'incubation. Cette différence est due à une diminution du nombre des récepteurs, et non de leur affinité, sous l'effet du génotype dw. Le même résultat, mais plus intense encore, est observé chez les poules adultes. Chez le poulet en croissance, la liaison est moins élevée que chez l'adulte quel que soit le génotype, mais il y a toujours une légère différence significative entre les génotypes. La cause de ce moindre nombre de récepteurs hépatiques de la GH chez les poules naines n'est pas connue. Elle peut résulter de l'action primaire du gène de nanisme.

poulet / nanisme / récepteur de l'hormone de croissance

\footnotetext{
* Correspondence and reprints.
} 


\section{INTRODUCTION}

The hormonal profile of chickens carrying the sex-linked dwart gene ( $d w$ ) has been well characterised. Recent results describing the endocrinological and metabolic effects of this dwarf gene have been reviewed by Tixier-Boichard et al (1989) and by Decuypere et al (in press). Circulating triiodothyronine $\left(T_{3}\right)$ levels are depressed but growth hormone $(\mathrm{GH})$ concentrations in the plasma are elevated during the fast growing period (Scanes et al, 1983; Huybrechts et al, 1987). In spite of the high $\mathrm{GH}$ levels, plasma immunoreactive insulinlike growth factor I (IGF-I) remains low during this stage (Huybrechts et al, 1987). It also has been shown that after $\mathrm{GH}$ injection the absolute increase in IGF-I levels is much smaller in dwarf birds than in normal birds (Huybrechts et al, 1988).

In the chick embryo it has been found that dwarfs have lower $T_{3}$ levels at the time of air-sac penetration and decreased IGF-I levels at the time of hatching, but the dwarf gene does not cause any changes in other hormonal parameters of the thyrotrophic or somatotrophic axis during this stage of development (Huybrechts et al, 1989). $\mathrm{GH}$, which is able to stimulate the $5^{\prime}$-monodeiodinase $\left(5^{\prime} \mathrm{D}\right)$ enzyme that converts thyroxine $\left(T_{4}\right)$ into $T_{3}$, is not effective when injected on d 18 of incubation into dwarf embryos, although it can increase circulating $T_{3}$ levels in normal embryos (Kühn et al, 1986).

All these results support the hypothesis that sex-linked dwarf chickens lack or have reduced numbers of $\mathrm{GH}$ receptors. $\mathrm{A}$ reduction in hepatic $\mathrm{GH}$ receptors was first demonstrated in 20-wk-old broiler and Leghorn chickens bearing the dwarf gene (Leung et al, 1987). This was confirmed by our group in adult dwarf broiler breeders (Kühn et al, 1989). Since no information concerning possible differences between the genotypes was available during embryogenesis or during the period of fast growth where $\mathrm{GH}$ may play a crucial role, a comparative study of the hepatic $\mathrm{GH}$ receptor between normal and dwarf chickens was set up during these periods.

\section{MATERIALS AND METHODS}

All the animals used in this study issued from the mating between heterozygous sires and dwarf females of a medium-heavy laying strain, kindly provided by Dr Mérat (INRA, France). To distinguish dwarf and normal birds at an early stage, a linkage was made between the dwarf gene and the S,s gene for feather colour; this resulted in brown-feathered dwarf and whitefeathered normal birds.

The eggs were incubated at $37.5^{\circ} \mathrm{C}$ in a forced-draught incubator. After hatching, the birds were housed under a long-day photoperiod of $16 \mathrm{~h}$ light and $8 \mathrm{~h}$ darkness (16 L:8 D). Food and water were available ad libitum until experimentation.

After the animals had been killed (adult birds at the age of $2 \mathrm{yr}$ ), the livers were excised and frozen at $-20^{\circ} \mathrm{C}$ for analysis.

The hepatic $\mathrm{GH}$ receptors were determined as described earlier (Vanderpooten et al, 1989). Chicken GH (cGH) was purified from a crude pituitary extract by immuno-affinity chromatography using a monoclonal antibody. Purity was controlled by polyacrylamide gel electrophoresis and reversed phase HPLC (Berghman et al, 1988). This CGH preparation was iodinated to a specific activity of $100-200 \mu \mathrm{Ci} / \mu \mathrm{g}$, with the lodo-gen iodination reagent following the method of Fraker and Speck (1978).

Microsomal fractions from individual livers were prepared (Shiu et al, 1973) and stored at $-20{ }^{\circ} \mathrm{C}$. Livers of embryos were pooled. In order to remove endogenous hormone from the receptors, membranes were treated with a $3 \mathrm{M} \mathrm{MgCl}_{2}$ solution (Kelly et al, 1979), which resulted in a protein loss of $\approx 40 \%$. The treatment consisted of a 5-min incubation of $1 \mathrm{ml}$ of microsomal fraction with $1 \mathrm{ml}$ of $3 \mathrm{MgCl}_{2}$ at room temperature. After dilution with $2 \mathrm{ml}$ ice-old Tris- $\mathrm{HCl}$ buffer $(\mathrm{pH} 7.5 ; 25 \mathrm{mM})$ the mixture was centrifuged at $2000 \mathrm{~g}$ for $10 \mathrm{~min}$ at $4{ }^{\circ} \mathrm{C}$ and the pellet washed 
with $1 \mathrm{ml}$ Tris- $\mathrm{HCl}$ buffer. Finally, after centrifugation, the pellet was resuspended in Tris- $\mathrm{HCl}$ buffer containing $10 \mathrm{mM} \mathrm{CaCl} 2$ and $0.5 \%(\mathrm{w} / \mathrm{v})$ BSA (assay buffer). Protein concentration was estimated on these membranes using the method of Lowry, modified by Peterson (1977).

In order to test the efficiency of this $\mathrm{MgCl}_{2}$ treatment we incubated $125 \mathrm{I}-\mathrm{cGH}$ with untreated liver membranes and compared the remaining radioactivity which was specifically bound after the membranes had been treated with $\mathrm{MgCl}_{2}$ or with $\mathrm{H}_{2} \mathrm{O}$. This preliminary experiment demonstrated that all specifically bound $125 \mid-\mathrm{cGH}$ was removed by $\mathrm{MgCl}_{2}$.

Specific binding of $\mathrm{CGH}$ was determined by incubating $100 \mu{ }^{125}$-cGH $\left(35 \times 10^{3} \mathrm{cpm}\right)$ with $100 \mu \mathrm{l}$ membrane fraction, either in the presence or in the absence of an excess of unlabelled cGH $(500 \mathrm{ng} / 100 \mu \mathrm{l} / \mathrm{tube})$. Specific binding was calculated by subtracting nonspecific binding from total binding and expressed as \% of total $\mathrm{cpm}$ added, per $\mathrm{mg}$ protein.

After incubation at room temperature for 20 h, $2 \mathrm{ml}$ of ice-old assay buffer per tube was added. Following centrifugation for $10 \mathrm{~min}$ at 2000 $g\left(4{ }^{\circ} \mathrm{C}\right)$, the radioactivity in pellets was counted in a gamma counter (LKB-Packgamma II 1720).

Scatchard analyses were performed by incubating a fixed amount of membrane prepara- tions with a fixed amount of labelled hormone and increasing amounts of unlabelled hormone.

From these results the receptor-binding parameters (capacity and affinity) were calculated using the LIGAND program (Munson and Rodbard, 1980). This resulted in the mean \pm SEM of the affinity and capacity of Scatchard plots, performed in 3-8 replicates.

All results were expressed as the mean \pm SEM; the number of animals are given in the figures. Statistical analyses were carried out by 1 way analysis of variance (ANOVA) followed by the least significant difference test (Isd-test), when $F$ was significant. Since no individual results of the replicates of the Scatchard plots were available, but only means \pm SEM, affinity constants or binding capacities were compared using the Isd-test.

\section{RESULTS}

The specific binding of ${ }^{125} \mathrm{I}-\mathrm{cGH}$ to $\mathrm{MgCl}_{2}-$ treated liver microsomal fractions of normal and dwarf embryos from the 14th $d$ of incubation till the first day after hatching is shown in figure 1. A significantly higher

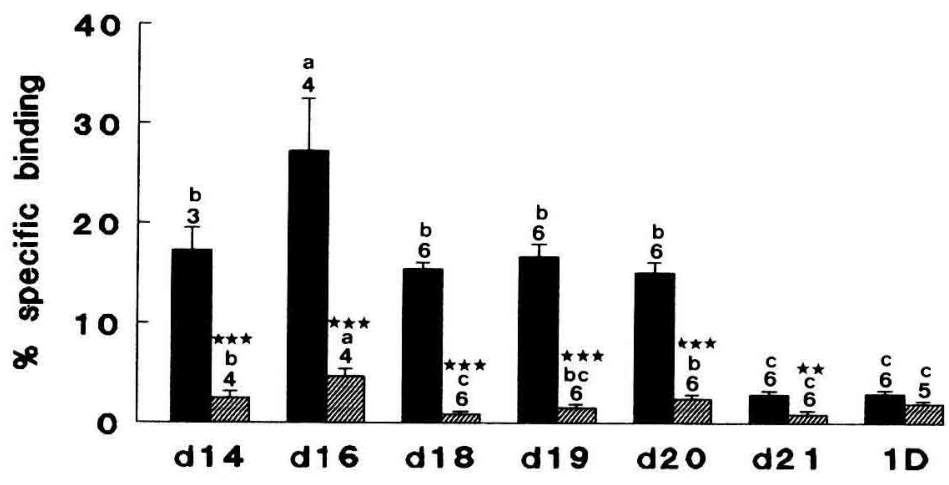

age

Fig 1. Percentage specific binding/mg protein of ${ }^{125} \mathrm{I}-\mathrm{CGH}$ to $\mathrm{MgCl}_{2}$ treated liver microsomal fractions of dwarf ( $\mathbb{Z}$ ) and normal $(\square)$ embryos. The amount of membrane proteins incubated varied from $0.48-0.72 \mathrm{mg} / 100 \mu \mathrm{l}$ for normal and from $0.61-0.68$ for dwarf embryos. Number of measurements on pooled livers is shown above bars. a-c: groups within the same genotype, sharing no common letter are significantly different (Dw: $P<0.001$; dw: $P<0.05$, ANOVA). ${ }^{* *} P<0.01,{ }^{* * *} P<0.001$ : significance between $\mathrm{Dw}$ and $\mathrm{dw}$ at each time point. Age: $d=$ embryos; $\mathrm{D}=$ post-hatching. 
binding was found in normal embryos compared to dwarts from d 14 till $d 20$ of incubation $(P<0.001$, except for $\mathrm{d} 21$ : $P<$ $0.01)$. The specific binding to the $\mathrm{GH}$ receptor in normal embryos decreased prior to hatching $(P<0.001)$ to values which were not different from dwarf values $1 \mathrm{~d}$ after hatching.

Scatchard plots were calculated when specific binding was high enough to allow precise determination of the binding parameters, which was not always the case in dwarts. These results are shown in figures $2 \mathrm{a}$ and $\mathrm{b}$. Affinity constants of the hepatic $\mathrm{GH}$ receptor did not change significantly during embryonic development or between the 2 genotypes, following the least significant difference test (Isd test, fig 2a). The binding capacity (expressed in $\mathrm{fmol} / \mathrm{mg}$ protein; fig $2 \mathrm{~b}$ ) of the hepatic $\mathrm{GH}$ receptor of dwarf embryos was significantly lower than the values found for the controls of the same age on the time points. Scatchard plots could be calculated for both genotypes (d 14, 16, 19 and 20).

Within the group of normal embryos we found a significant $(P<0.01)$ decrease in capacity of the hepatic $\mathrm{GH}$ receptor towards the end of incubation when compared to $d 14$.

After hatching, the specific binding to the hepatic $\mathrm{GH}$ receptor was determined in 2, 3, 5 and 8-wk-old normal growing and dwarf birds (fig 3 ). During this period a difference between the 2 genotypes re- mained $(P<0.01)$, although binding was low for normal chickens when compared to values obtained in embryos and aduit birds. Scatchard plots could only be calculated for the normal growing birds. Figure 4 shows a representative Scatchard plot for the 2-wk-oid birds. The affinity constants and binding capacities are shown in table I. These parameters did not change significantly (Isd-test) between the ages examined during this rapid growth period.

In adult animals, the difference in $\mathrm{GH}$ binding between both genotypes was very pronounced: for the normal adults we found a specific binding of $33.41 \pm 5.35 \%$ per $\mathrm{mg}$ protein ( $n=8$ ) while only 5 out of 7 dwarf adults showed positive specific binding: $0.75 \pm 0.23 \%$ per $\mathrm{mg}$ protein $(n=5, P$ $<0.001$, ANOVA) (fig 3). The low binding percentage did not allow calculation of the binding parameters in dwart birds. In normal birds, an affinity constant of $4.93 \pm$ $0.8310^{10} \mathrm{M}^{-1}\left(P<0.05\right.$ compared to $K_{\mathrm{a}}$ values obtained for growing chicks) and a capacity of $5.63 \pm 0.51 \mathrm{fmol} / \mathrm{mg}$ protein $\left(P<0.001\right.$ compared to $B_{\max }$ values obtained for growing normal chicks) were found.

\section{DISCUSSION}

The ontogenic study of the hepatic $\mathrm{GH}$ receptor in the normal (Dw) growing embryos and chicks indicates that binding to the $\mathrm{GH}$

Table I. LIGAND calculated affinity $\left(K_{\mathrm{a}}\right)$ and capacity $\left(B_{\max }\right)$ values for the hepatic GH receptors of 2 , 3, 5 and 8-wk-old Dw chickens.

\begin{tabular}{ccccc}
\hline Age $(w k)$ & 2 & 3 & 5 & 8 \\
\hline$K_{\mathrm{a}}\left(10^{10} \mathrm{M}^{-1}\right)$ & $1.64 \pm 0.82$ & $1.91 \pm 1.11$ & $2.28 \pm 0.73$ & $1.11 \pm 0.35$ \\
$B_{\max }($ fmol/mg protein $)$ & $1.49 \pm 0.61$ & $0.97 \pm 0.45$ & $0.98 \pm 0.25$ & $1.92 \pm 0.46$ \\
\hline
\end{tabular}


receptor decreases towards the end of incubation, is low at time of hatching, and remains relatively low during the first weeks after hatching, compared to the binding values obtained in 14-20-d-old embryos and adults. This decline towards the end of incubation and the low binding in posthatch chicks has also been found in chickens of a commercial layer strain (Vander- pooten et al, 1990). Comparing dwarf and normal chickens, it is obvious that as early as $\mathrm{d} 14$ of embryonic development there is a difference in hepatic $\mathrm{GH}$ receptor binding, and this is due to a lower binding capacity in the liver of the dwarf embryos. This difference disappears transiently at the time of hatching when binding for the normal embryos decreases. The de-
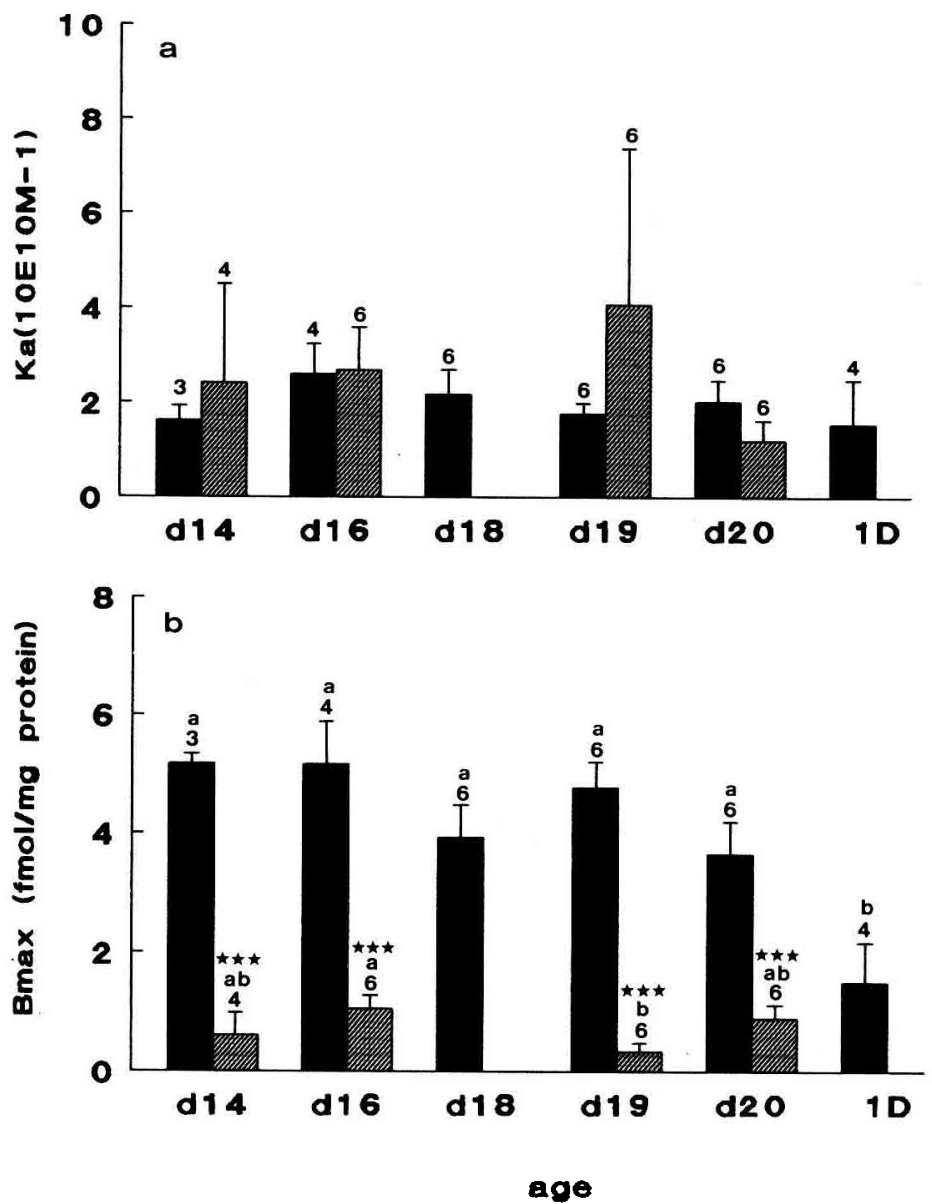

Fig 2. LIGAND calculated affinity (a) and capacity (b) values for hepatic GH receptors of dwarf (目) and normal $(\square)$ embryos. Scatchard plots were calculated from experiments using increasing amounts of cGH. Number of measurements on pooled livers is shown above bars. a: No significant differences were found by Isd-test. b: $a-b$ : groups within the same genotype sharing no common letter are significantly different $\left(P<0.01\right.$, Isd-test). ${ }^{* \star *} P<0.001$ : significance between $\mathrm{Dw}$ and $\mathrm{dw}$ at each time point. Age: $d=$ embryos; $D=$ post-hatching. 


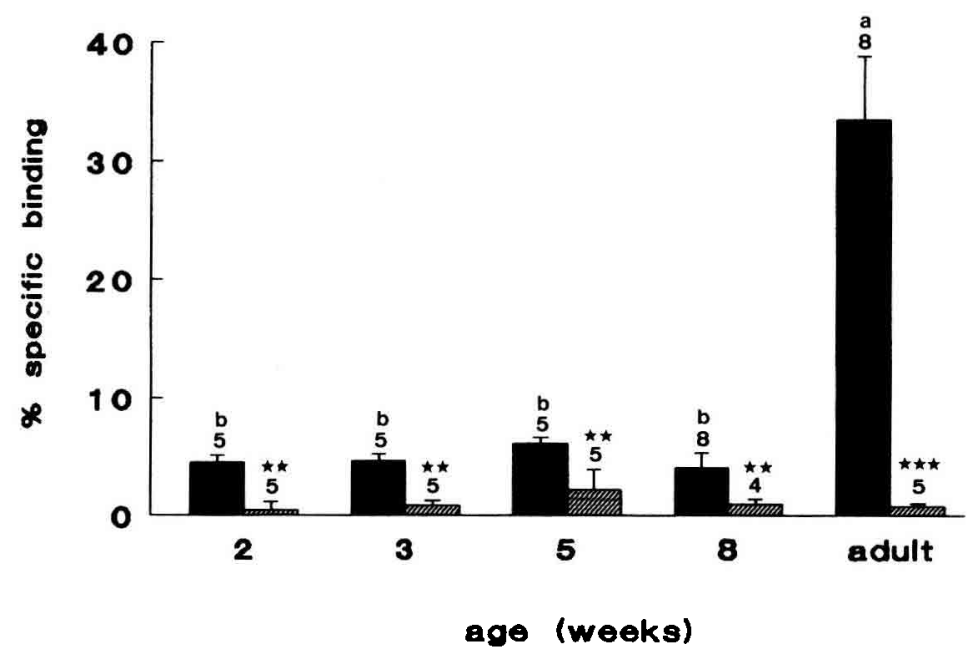

Fig 3. Percentage specific binding/mg protein of $125 \mathrm{I}-\mathrm{cGH}$ to $\mathrm{MgCl}_{2}$-treated liver microsomal fractions of dwarf $(\mathbb{Z})$ and normal $(\square)$ chickens during postnatal development. The amount of membrane proteins incubated was 0.53 and $0.50 \mathrm{mg} / 100 \mu \mathrm{l}$ for normal and dwarf adults respectively, and varied from $0.78-0.95 \mathrm{mg} / 100 \mu \mathrm{l}$ for normal chicks and from $0.89-1.02 \mathrm{mg} / 100 \mu \mathrm{l}$ for dwarf chicks. Numbers of animals per group are shown above bars. $a-b$ : Dw groups sharing no common letter are significantly different $\left(P<0.001\right.$ : ANOVA). No significant difference was found between dw groups. ${ }^{* *} P<$ $0.01,{ }^{\star * \star} P<0.001$ : significance between Dw and $d w$ at each time point (ANOVA).

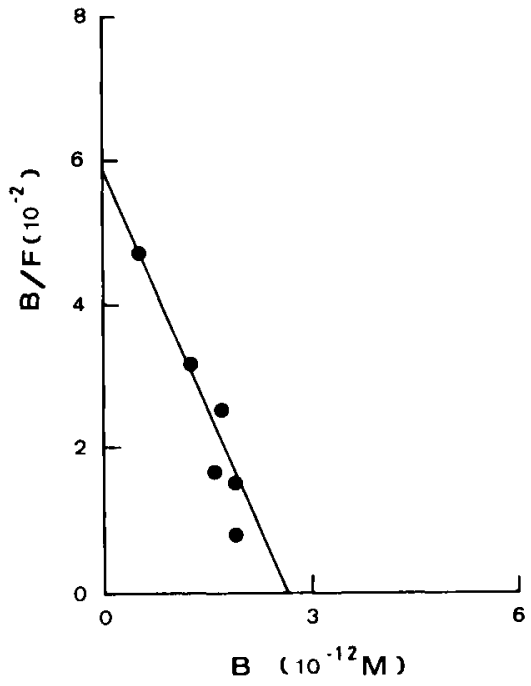

Fig 4. Scatchard plot for the hepatic GH receptor of 2-wk-old Dw chickens, calculated from a competition experiment using increasing amounts of $\mathrm{cGH}$. pressed $\mathrm{GH}$ receptor number in dwarfs can explain why $\mathrm{GH}$ could not stimulate the 5'-monodeiodinase enzyme to convert $T_{4}$ into $T_{3}$ in these embryos (Kühn et al, 1986). The effect of the dwarf gene may also play a major role in the low plasma $T_{3}$ as well as IGF-I levels observed in juvenile chickens (Scanes et al, 1983; Huybrechts et al, 1986) and hence be an important factor in determining the decreased growth during postnatal development (TixierBoichard et al, 1989).

During the prenatal period no difference in circulating $\mathrm{GH}$ was found between dwarf and normal birds; this only occurred from the 3rd wk posthatch till the 18th wk ( $\mathrm{Hu}-$ ybrechts et al, 1987). Therefore it is not likely that the depressed hepatic $\mathrm{GH}$ binding capacity in the dwarf embryos is caused by a GH induced down-regulation, since at that time of development, circulat- 
ing $\mathrm{GH}$ levels are equal for both genotypes.

After hatching we found a low binding in dwarfs and in normal chicks, but the difference between the 2 genotypes remained, although the absolute difference was much smaller. Leung et al (1987) found similar binding characteristics in 6 and 8 -wk-old broiler chicks: specific binding did not exceed $4 \%$ of total cpm. They also demonstrated a significantly lower binding for the 6 and 8-wk-old, but not the 2-wk-old chicks (Leung et al, 1984).

Circulating $\mathrm{GH}$ concentrations in the domestic fowl are elevated at the time of hatching and during the first weeks posthatch. This period corresponds with the occurrence of low binding percentages found in the normal growing chicks in this study. However, the hypothesis that the GH receptors in the microsomal fractions are occupied to a great extent is excluded since they have been desaturated by the $\mathrm{MgCl}_{2}$ treatment. A possible explanation is downregulation by the high circulating $\mathrm{GH}$ concentrations. Arguments in support of this hypothesis have been found in studies on hypophysectomised chicks. Hypophysectomy resulted in a marked decrease of circulating $\mathrm{GH}$, while an obvious increase in the number of hepatic $\mathrm{GH}$ receptors was found; this effect was reversed by acute $\mathrm{GH}$ administration. Since the number of available $\mathrm{GH}$ receptors depends on the balance between receptor internalisation and degradation on the one hand, and receptor recycling plus new synthesis on the other (Posner et al, 1981), the observed down-regulation in growing chicks may be the result of a shift in balance towards a higher receptor degradation, due to an increased receptor activity during this period of fast growth. This argument is supported by the findings of Husman et al (1988) who suggested that down-regulation of somato- genic receptors in rat liver is the result of transport of internalised ligand-receptor complexes to lysosomes, probably to degrade the ligand and/or receptor and terminate the hormone action. In addition, Roupas and Herington (1989) also suggested that $\mathrm{GH}$ receptors undergo a ligandbinding induced internalisation and that subsequently $75 \%$ of these internalised receptors are degraded and not recycled.

In the adult stage, the expression of the dwarf gene was most evident: dwarf chickens did not show any specific binding at all $(<0.5 \%)$, while the controls of the same age showed a high specific binding to the $\mathrm{GH}$ receptor. In a previous report on adult dwarf broiler breeders, we still found some specific binding for the dwarfs. Calculation of the Scatchard plots demonstrated that the lower binding was due to a decreased capacity of the hepatic GH receptor (Kühn et al, 1989). These results confirm those of Leung et al (1987) who found the same difference in expression of the dwarf gene depending on genetic background.

The cause of the decreased number of hepatic GH receptors in the sex-linked dwarf chicken remains to be investigated but it may well be the consequence of a mutation in the $\mathrm{GH}$ receptor gene, as has been found in Laron dwarfs (Amselem et al, 1989; Godowski et al, 1989).

When the comparison between the 2 genotypes is examined, it appears that there is a better correlation between $\mathrm{GH}$ binding and growth than between circulating $\mathrm{GH}$ and growth, especially between strain comparisons, as has also been pointed out by Leung et al (1987). However, when the developmental pattern of $\mathrm{GH}$ binding in normal growing chickens is considered, this correlation no longer fits: $\mathrm{GH}$ binding is lowest when growth rate is high. 


\section{ACKNOWLEDGMENTS}

This work was supported by a grant from the National Fund for Scientific Research, Belgium (NFWO): FKFO 2.0039.90. A Vanderpooten was supported by the Instituut ter Aanmoediging van het Wetenschappelijk Onderzoek in de Nijverheid en de Landbouw (IWONL) and L Huybrechts by the National Fund for Scientific Research (NFWO). We are indebted to $P$ Mérat for donating the fertilised eggs and livers of adult animals and to $L$ Berghman for the affinitypurified $\mathrm{CGH}$.

\section{REFERENCES}

Amselem S, Duquesnoy P, Attree O, Novelli G, Bousnina S, Postel-Vinay MC, Goossens M (1989) Laron dwarfism and mutations of the growth hormone receptor gene. New Engl $J$ Med 321, 989-995

Berghman LR, Van Beeumen J, Decuypere E, Kühn ER, Vandesande F (1988) One-step purification of chicken growth hormone from a crude pituitary extract by use of monoclonal immunoadsorbent. $J$ Endocrinol 118, 381-387

Decuypere E, Huybrechts LM, Tixier-Boichard M, Kühn ER, Mérat $P$ (1990) Physiological alterations associated with the chicken sexlinked dwarfing gene. Crit Rev Poult Biol (in press)

Fraker PJ, Speck JC (1978) Protein and cellmembrane iodinations with a sparingly soluble chloramide 1,3,4,6-tetrachloro-3A,6Adiphenylglycoluril. Biochem Biophys Res Commun 80, 849-857

Godowski PJ, Leung DW, Meacham LR, Galgani JP, Hellmis R, Keret R, Rotwein PS, Parks JS, Laron Z, Wood WI (1989) Characterization of the human growth-hormone receptor gene and demonstration of a partial gene deletion in two patients with Laron-type dwarfism. Proc Natl Acad Sci USA 86, 8083-8087

Husman B, Gustafsson JA, Andersson G (1988) Receptor-mediated endocytosis and degradation of bovine growth hormone in rat liver. Mol Cell Endocrinol 59, 13-25
Huybrechts LM, Kühn ER, Mérat $P$, Decuypere $E$, Michels $H$, Tixier M (1986) Endocrinological effects of the sex-linked dwarf gene. I. Effect on growth and plasma thyroid hormone concentration. Proc 7th Eur Poult Conf, Paris, 950-954

Huybrechts LM, Kühn ER, Decuypere E, Mérat $P$, Scanes CG (1987) Plasma concentrations of growth hormone and somatomedin $C$ in dwarf and normal chickens. Reprod Nutr Dev 27, 547-553

Huybrechts LM, Michielsen R, Darras VM, Berghman LR, Decuypere E, Kühn ER (1988) Effect of a methimazole induced hypothyroidism on a growth hormone induced insulin-like growth factor I response in normal and sex-linked dwarf domestic fowl. Med Sci Res 16, 85-86

Huybrechts LM, Michielsen R, Darras VM, Buonomo FC, Kühn ER, Decuypere $E$ (1989) Effect of the sex-linked dwarf gene on thyrotrophic and somatotrophic axes in the chick embryo. Reprod Nutr Dev 29, 219-226

Kelly PA, Leblanc G, Diiane J (1979) Estimation of total prolactin-binding sites after in vitro desaturation. Endocrinology 104, 1631-1638

Kühn ER, Huybrechts LM, Decuypere E, Mérat $P$ (1986) Endocrinological effects of the sexlinked dwarf gene. III. Prolactin and growth hormone fail to increase the liver T4 5'monodeiodinase activity in the sex-linked dwart chick embryo. Proc 7th Eur Poult Conf Paris, 965-969

Kühn ER, Huybrechts LM, Vanderpooten A, Berghman LR (1989) A decreased capacity of hepatic growth hormone $(\mathrm{GH})$ receptors and failure of thyrotrophin releasing hormone to stimulate the peripheral conversion of thyroxine into triiodothyronine in sex-linked dwarf broiler breeders. Reprod Nutr Dev 29, 461-467

Leung FC, Gillet J, Lilburn MS, Kopchick J (1984) Analysis of growth-hormone receptors and genes in sex-linked dwarf chickens. $J$ Steroid Biochem 20, 1557

Leung FC, Styles WJ, Rosenblum Cl, Lilburn MS, Marsh JA (1987) Diminished hepatic growth hormone receptor binding in sexlinked dwarf broiler and Leghorn chickens. Proc Soc Exp Biol Med 184, 234-238 
Munson PJ, Rodbard D (1980) LIGAND: a versatile computerized approach for characterization of ligand-binding systems. Anal Biochem 107, 220-239

Peterson GL (1977) A simplification of the protein assay method of Lowry et al which is more generally applicable. Anal Biochem 83, 346-356

Posner BI, Bergeron JJM, Jozefsberg Z, Khan MN, Khan RJ, Patel RA, Sikstrom RA, Verma AK (1981) Polypeptide hormones: intracellular receptors and internalization. Recent Prog Horm Res 37, 539-582

Roupas P, Herington AC (1989) Cellular mechanisms in the processing of growth hormone and its receptor. Mol Cell Endocrinol 61, 1-12

Scanes CG, Marsh J, Decuypere E, Rudas $P$ (1983) Abnormalities in the plasma concentrations of thyroxine, triiodothyronine and growth hormone in the sex-linked dwarf and autosomal dwarf White Leghorn domestic fowl (Gallus domesticus). J Endocrinol 97, 127-135

Shiu RPC, Kelly PC, Friesen HG (1973) Radioreceptor assay for prolactin and other lactogenic hormones. Science 180, 968-970

Tixier-Boichard $M$, Huybrechts LM, Kühn ER, Decuypere E, Charrier J, Mongin P (1989) Physiological studies on the sex-linked dwarfism of the fowl: a review on the search for the gene's primary effect. Genet Sel Evol 21, 217-234

Vanderpooten A, Dewil E, Decuypere E, Kühn ER (1989) The effect of fasting on the growth hormone receptor in liver membranes of adult chickens. Med Sci Res 17, 1301-1032

Vanderpooten A, Decuypere E, Kühn (1990) Ontogeny of the hepatic growth hormone receptor in the chicken. $J$ Endocrinol Invest 13 (suppl 2), 275 (abstr) 